Tomasz Ewertowski

(Uniwersytet im. Adama Mickiewicza w Poznaniu, Shanghai International Studies University)

\author{
'YELLOW RACE' IN POLISH AND SERBIAN TRAVEL WRITING \\ FROM THE SECOND HALF OF THE $19^{\text {TH }}$ CENTURY \\ AND THE FIRST HALF OF THE $20^{\mathrm{TH}}$ CENTURY*
}

[...] suddenly I saw a Chinese. Although in Europe I had seen Chinese acrobats, athletes performing, but in real-life situations [...] I have not yet seen a Chinese. Hence I was scrutinizing him attentively, because we were walking in the same direction. He was well-built, bony, of yellow complexion, actually swarthy yellow, like an old parchment $[\ldots]{ }^{1}$

During his world tour in the years 1888-1890, Hugo Zapałowicz (1852-1917), a Polish natural scientist, traveler, and military man encountered Chinese people for the very first time in his life. His words, quoted above, expose a number of relevant issues. According to Vladimir Gvozden, travel writing is a textual trace of the real journey, documenting the encounter with space, time, and society. ${ }^{2}$ Zapałowicz felt a certain excitement after seeing a Chinese, which triggers in him a passion for observation, thus, we can say that travel writing gives us an access to real encounters with 'otherness'. However, descriptions of foreign countries link "unknown entities to known reference points, and to familiar frameworks of meaning and understanding". ${ }^{3}$ The singular event of seeing the first Chinese "in real-life situations" is mediated "in writing" by an entanglement of conventions and stereotypes. The skin of a Chinese is not yellow (unless someone suffers from jaundice), and Zapałowicz also noticed that the skin of the person he had seen was swarthy; however, the pressure of cultural discourse made him use the word "yellow" eventually. Furthermore, he had just seen a Chinese for the first time in his life and he did not even talk to him, but even such a short meeting was enough to make Zapałowicz write a few pages filled with stereotypes. This simple example illustrates the point that travelogues tend to show the reality of the places

\footnotetext{
* This work was supported by the National Centre of Science grant no. 2014/15/D/HS2/00801, Decision Number DEC-2014/15/D/HS2/00801).

${ }^{1}$ Hugo Zapałowicz, Jedna z podróży na około Ziemi. Tom I, Lwów: Księgarnia Gubrynowicza i Schmidta 1899, p. 629. All translations into English are our own, unless otherwise indicated. The original says:: "[...] nagle dostrzegłem - Chińczyka. Widywałem wprawdzie w Europie produkujących się chińskich akrobatów, atletów, ale w naturze [...] jeszcze Chińczyka nie widziałem. Przypatrywałem mu się przeto uważnie, bo szliśmy w jedną stronę. Był słusznego wzrostu, kościsty, cery żółtej, właściwie śniado żółtej, jak stary pergamin [...]”.

${ }^{2}$ Vladimir Gvozden, Srpska putopisna kultura 1914-1940. Studija o hronotopičnosti susreta, Beograd: Službeni glasnik 2011. All Serbian language texts are written in Latin alphabet.

${ }^{3}$ Carl Thompson, Travel writing, London-New York: Routledge 2011, p. 67.
} 
they described which, nevertheless, are constructed according to the writers' and their projected readers' knowledge and values. In fictional literature, race issues are presented with a greater level of correspondence with the dominant discourse of the epoch, being predominantly the product of a writer's imagination. In travel writing, we can observe how the content of observation is being negotiated with prejudices, values and intellectual tradition.

Therefore, in this paper, we will focus on travelogues, while only referring contextually to fictional works. The main goal is to show how a discourse on the so-called yellow race functioned in the Polish and Serbian travel writing from the second half of the $19^{\text {th }}$ century and first half of the $20^{\text {th }}$ century. An analysis of the semantics of the term 'yellow race' is also proffered.

Paying attention to Serbian and Polish authors can broaden our understanding of the imperial and racial dimension of representation of China. In the modern period, Poland and Serbia did not take part in exploitation of China; on the contrary, these countries themselves became objects of imperial domination. Nevertheless, when travelers from Poland or Serbia visited China, they often represented imperial institutions of foreign powers, e.g. as soldiers in the Russian army. Their outlook on the world was formed by intellectual trends born in Western Europe, like Darwinism. However, Poles and Serbs, being victims of imperialism themselves, were in a better position to understand the people of this East Asian nation. Therefore, we find an interesting ambivalence. Additionally, choosing Polish and Serbian travel writings also allows us to see whether representatives of a Catholic Slavic nation and an Orthodox Slavic nation had different attitude towards race issues. ${ }^{4}$

HOW DID THE CHINESE END UP BEING CONSIDERED 'YELLOW'?

In three very different attempts to give a broad overview of the development of race and racial thinking in the West, namely works by Ivan Hannaford, ${ }^{5}$ George Fredrickson ${ }^{6}$ and Francisco Bethencourt, ${ }^{7}$ the $18^{\text {th }}$ century is considered as the time in which modern racism was born, and its apogee was the first half of the $20^{\text {th }}$ century. How can the concept of the yellow race be posited in this general framework?

\footnotetext{
${ }^{4}$ For general information about Polish travel writing on China, see Edward Kajdański, Dlugi cień wielkiego muru: jak Polacy odkrywali Chiny, Warszawa: Oficyna Naukowa 2005; Marian Kałuski, Polacy w Chinach, Warszawa: Instytut Wydawniczy PAX 2001; Leszek Cyrzyk, Literatura podróżnicza o Chinach w Polsce XIX w., "Przegląd Orientalistyczny" 1966, vol. 3(59), pp. 205-216. About Serbian travel writing, see anthologies Kapija od žada. Putopisi Srba o Kini: 1725-1935, ed. Radosav Pušić, Beograd: Biblioteka grada; Želnid 1998; Podnebesko carstvo. Srbi o Kini 1725-1940 (putopisi i članci), ed. Radosav Pušić, Beograd: Čigoja štampa 2006.

${ }^{5}$ Ivan Hannaford, Race: The History of an Idea in the West, Baltimore, London, Washington: Hopkins University Pres, Woodrow Wilson Center Press 1996.

${ }^{6}$ George M. Fredrickson, Racism. A Short History, Princeton-Oxford: Princeton University Press 2002.

${ }^{7}$ Francisco Bethencourt, Racisms. From the Crusades to the Twentieth Century, Princeton-Oxford: Princeton University Press 2013.
} 
First, it should be said that the yellow color has a significant meaning in Chinese tradition, being the color of the Emperor and of life-giving Earth. Besides, one of the important legendary figures in Chinese history is the Yellow Emperor, such that the Chinese sometimes refer to themselves as "Sons of the Yellow Emperor". However, such usage did not refer to skin color. David Mungello states that prior to the $18^{\text {th }}$ century, both the Chinese and Japanese were usually considered 'white' by Europeans, which was, according to Mungello, connected with a respect for the achievements of East Asian civilization and hopes for the Christianization of China. ${ }^{8}$ Such views started to change in the $18^{\text {th }}$ century, so that later in the $19^{\text {th }}$ century, the image of China was dominated by the stereotype of a conservative, despotic society. Even if chinoiserie fashion was blooming and some Enlightenment authors idealized Chinese society, the economic and military development of Western powers, emergence of imaginary opposition between the West and East, and the formation of progressive social ideas led to a negative assessment of Chinese civilization, ${ }^{9}$ which was also reflected in the descriptions of skin color.

The process behind the view of Chinese and other East Asians as yellow is analyzed in detail by Michel Keevak. He claims that in early modern accounts, the Chinese were described as white, with a remark that inhabitants of the southern provinces have darker complexion. In the $17^{\text {th }}$ century, the yellow color might well be attributed to Indians, but not the Chinese. ${ }^{10}$ In Carl Linnaeus Systema naturae (first edition) from 1735, Asians are called fuscus (brown, swarthy), and only in the $10^{\text {th }}$ edition from 1758-59 were they described with the word luridus (pale yellow). ${ }^{11}$ The view that the Chinese and other East Asians have yellow skin became firmly established with Johann Friedrich Blumenbach's De generis humani varietate native. In the final third edition from 1795, Blumenbach distinguished five races: Caucasian as the oldest and primeval one, with Mongolian and Ethiopian as being the furthest away from white Caucasians. The Mongolian race was described using the word gilvus (pale yellow) ${ }^{12}$ Because of the association with a history of conquests by Genghis Khan and his successors, the idea of a Mongolian race was linked with the stereotype of being hordes of Asian invaders. In the second half of the $19^{\text {th }}$ century, this stereotype was actualized in the concept of the 'yellow peril' referring to Japan's rapid development, which led to European powers fearing for their possessions in Asia. Furthermore, after the so-called opium wars, the Chinese people were free to emigrate and were often sought out as cheap labor force in European colonial possessions or in the Americas. The scale of this emigration made Europeans and Americans fearful of its demographic and cultural impact.

\footnotetext{
${ }^{8}$ David Emil Mungello, The Great Encounter of China and the West, 1500-1800, Plymouth: Rowman \& Littlefield Publishing Group, Inc. 2009, pp. 130-134.

${ }^{9}$ About changes in the perception of China see Raymond Dawson, The Chinese Chameleon. An Analysis of European Conceptions of Chinese Civilisation, New York: Oxford University Press 1967, pp. 65-89; Colin Mackerras, Western Images of China, Oxford, New York: Oxford University Press 1989, pp. 28-65; Александр Владимирович Лукин, Медведь наблюдает за драконом. Образ Китая в России в XVII-XXI веках, Москва: Восток-Запад: АСТ 2007, pp. 46-50.

${ }^{10}$ Michael Keevak, Becoming Yellow. A Short History of Racial Thinking, Princeton-Oxford: Princeton University Press 2011, pp. 45-48.

${ }^{11}$ Ibidem, p. 51.

${ }^{12}$ Ibidem, pp. 62-63.
} 
We will focus on the second half of the $19^{\text {th }}$ century and the first half of the $20^{\text {th }}$ century, because then we encounter a fully formed discourse about the socalled yellow race. However, a corpus of Polish and Serbian travelogues confirms Bethencourt's claim that racism revitalizes older stereotypes. For example, the first known Serbian traveler to China, Sava Vladislavić (1668-1738), a diplomat in the court of the Russian tsars, did not use the word 'race' and did not mention yellow skin color in his report about China; however, he gave a description of the Chinese as cunning, haughty barbarians, ${ }^{13}$ a stereotype that was later used in racial discourse.

\section{CONFLICT OF RACES}

'Yellow', as a characteristic of the Middle Kingdom, appears already in the title of a book by Ozren Subotić (1873-1951) called Iz žutog carstva (From the Yellow Kingdom). This author visited East Asia at the beginning of the $20^{\text {th }}$ century when he was serving in the Russian army and studying at the Eastern Institute in Vladivostok. ${ }^{14}$ The term 'yellow' in the title of his book does not refer to a racial discourse on skin color, but rather to the aforementioned Chinese tradition of ascribing great importance to the yellow color. In Subotić's text, quite frequently we find references to "the yellow race" or "yellow skin"; however, often these words are written in italics and put in a context of irony. For example, Subotić describes the plundering of a Chinese intellectual's house by European soldiers during military action against the Yihetuan Movement (so-called Boxer Rebellion). His attitude towards the owner of the house is full of admiration: "He is only a despised Chinese, lower race, and his face has a yellow color - but this time this yellow face of despised barbarian is infinitely higher than the other, cultural, white face". ${ }^{15}$ Subotic's remarks on the yellow race often have a subversive character, which can be called 'a persiflage'. Although the cliché of racial discourse is used, its fundamental ideological consequence - i.e. a conviction about a hierarchy of two races - is undermined.

Subotic calls the Russian-Japanese conflict the first war between two races; nevertheless, he does not elaborate on implications of this formulation. Examples of a distinctive discourse on a conflict between a white and yellow race are found in the writings of a Serbian traveler, Milorad Rajčević, and Polish reporter,

\footnotetext{
${ }^{13}$ About Vladislavić, his mission and his report see Sava Vladislavić, Tajna informacija o snazi i stanju kineske države. Секретная информація о силе и состояніи китайскаго государства, ed. Vladimir Davidović, Beograd: Radio-televizija Srbije 2011; Jovan Dučić, Grof Sava Vladislavić: jedan Srbin diplomat na dvoru Petra Velikog i Katarine I, Valjevo: Glas crkve 2004; Владимир Степанович Мясников, Посольство С.Л. Владиславича-Рагузинского в Пекин, in: Русско-китайские отношения в XVIII веку. Том II. 1725-1727, ed. Владимир Степанович Мясников, Москва: Наука 1990; Tomasz Ewertowski, Slika Kine u "Tajnoj informaciji o snazi i stanju kineskog carstva” Save Vladislavića, "Dositejev vrt" 2014, vol. 2, pp. 71-93.

${ }^{14}$ About Subotić's life and work see Darijuš Samii, Ozren Subotić - novosadski istraživač Dalekog istoka, "Sveske za istoriju Novog Sada" 2016, no. 17, pp. 41-45.

${ }^{15}$ Ozren Subotić, Iz žutog carstva, Novi Sad: Natošević 1921, p. 76.
} 
Roman Fajans (1903-1976). In the first half of the $20^{\text {th }}$ century, Rajčević traveled the world over. In 1910-1911, he journeyed around Asia. When characterizing the Chinese, he declares that they are abominable not only because of race, but also because of their character, which suggests that the author uses the term 'race' mostly in reference to physical traits. As members of the yellow (Mongolian) race, Rajčević enumerates not only the Chinese and the Japanese, but also Tibetans, Thais, the Burmese, and Tunguses. In his account of a trip to Manchuria, a considerable attention is paid to the Russian-Japanese war of 1904-1905, and with this background he introduces the topic of war between races. The Serbian traveler writes that some Europeans hated Russians (as Slavs) so much that they preferred a defeat of their own race by those yellow people. We can see a tertiary, hierarchical construction of identity: a race, a language-cultural group, a nation. Loyalty to one's own race should be more important than political interests, so Europeans who wish no victory for the Russians betray their own race. ${ }^{16}$ In general, statements by the Serbian globetrotter are very biased and shallow, e.g. Japanese expansion to the Asian continent is criticized by him as politically motivated; however, without hesitation he prizes Russian imperial undertakings. Rajčević's example shows that writings of a tourist who travels without intellectual preparations often remain within realm of simple impressions and stereotypes.

More sophisticated are the remarks on conflict between races by Roman Fajans (1903-1976), one of the most highly recognized Polish reporters from the 1930s. Fajans traveled around China in 1937-1938, and on the basis of his observations prepared a book entitled $W$ Chinach znowu wojna (A war in China Once Again). Usually, Fajans uses terms such as 'white race' and 'yellow race' as neutral expressions, the former in reference to Europeans and Americans, the latter to the Chinese and Japanese. He does not present negative and stereotypical characteristics like Rajčević and often refers to interviews with the Japanese and Chinese, which gives his book a more pluralistic standpoint. We can observe a difference between writings of a tourist, and an analytical gaze of a journalist. However, Fajans's own ultimate allegiance is not disputed; while writing on different aspects of European colonialism, he proudly calls Singapore a masterpiece of white men or displays anxiety about shrinking positions of the white race in Asia. Rajčević's account is written with the memory of Russo-Japanese war in mind, whereas the work of Fajans is dominated by the second Sino-Japanese war and an imminent clash between great powers in East Asia. Japanese expansionism is presented as extension of the 'yellow race', leading to inevitable conflict with the 'white' colonial empires. However, racial issues are not seen as a trigger of the conflict, as more attention is given to economy and geopolitics. As we have seen, Rajčević mentioned situations in which lines of international conflicts cross racial distinctions, criticizing people who act against their own race. Fajans also describes such situations of which the most distinctive example is his conversation with a Chinese intellectual, Doctor Lin. Fajans's remark - that in Europe there is an

\footnotetext{
${ }^{16}$ Another Serbian author he presented a Slavophile interpretation of Russian-Japanese war was Milutin Velimirović (1893-1973), e.g. he stated that all Slavic peoples were waiting for Russian victory (Milutin Velimirović, Kroz Kinu: putopis, Beograd: S.B. Cvijanović 1930, p. 9). Such Slavophile claims did not recognize the support for the Japanese case among Poles (David Crowley, Seeing Japan, Imagining Poland: Polish Art and the Russo-Japanese War, "The Russian Review" 2008, vol. 67, no. January, pp. 50-69).
} 
opinion that xenophobia towards whites will turn out to be stronger than the current Chinese hate for the Japanese invaders and that sooner or later Asian nations will unite under Nippon leadership to chase Europeans away from Asia - is countered by Lin that the Japanese will never be considered 'brothers' again. Nevertheless, it is worth remembering that even if in the description of international situations Fajans emphasizes economic, social and geopolitical factors, still he does not undermine the whole racial discourse. It is not surprising, because in general his views situated him closer to the right side of the political scene in 1930 .

\section{INTERRACIAL RELATIONSHIPS}

In his Colonial Desire. Hybridity in Theory, Culture and Race, Robert Young emphasizes the importance of sexuality and interracial relations for the $19^{\text {th }}$ and $20^{\text {th }}$ century discourse on race..$^{17}$ It is important to examine how this issue was presented in travel writings on China. Konstanty Symonolewicz (1884-1959), who received an orientalist education and worked in China (mostly as a diplomat during 1912-1930, and again for a short period after the Second World War), left behind two books and a number of articles. ${ }^{18}$ Symonolewicz often writes about the Chinese positively and criticises actions of Europeans. That said, his overall outlook is clear: the Mongolian race has its own special traits that are "a total contrast of ours" ${ }^{19}$ such that even with mutual liking serious communication is not possible. Such an attitude is reflected in his assessment of mixed marriages. $\mathrm{He}$ describes a few unsuccessful relations between Russian women and Chinese men and comments that both sides cannot be happy, because they represent two different poles: East and West. ${ }^{20}$ It is also worth paying attention to some semantic instability here. In one place, he writes about the Sino-Japanese relation as a combination of two races ${ }^{21}$ and in another place he calls the son of a Chinese and Japanese couple 'a mixture of two races'. ${ }^{22}$ Therefore, on the one hand, the writer refers to the traditional division of white and yellow race, linking it not only with biological issues, but also with cultural differences. However, he also uses the word 'race' with a meaning that is close to a 'nation'. ${ }^{23}$

\footnotetext{
${ }^{17}$ Robert J.C. Young, Colonial desire: hybridity in theory, culture, and race, London-New York: Routledge 1995.

${ }^{18}$ About Symonolewicz see: Edward Kajdański, Dlugi cień wielkiego muru: jak Polacy odkrywali Chiny..., pp. 323-340; Konstanty Symonolewicz - orientalista, dyplomata, opiekun Polonii Mandżurskiej, ed. Adam Winiarz, Szczecin: Książnica Pomorska im. Stanisława Staszica w Szczecinie 2012

${ }^{19}$ Konstanty Symonolewicz, Moi Chińczycy. 18 lat w Chinach, Warszawa: Biblioteka Polska 1938, p. 9 .

${ }^{20}$ Ibidem, p. 93.

${ }^{21}$ Ibidem, p. 67.

${ }^{22}$ Ibidem, p. 197.

${ }^{23}$ Compare with a remark by Magdalena Gawin that in Polish eugenics, the term 'race' was used in three main contexts: firstly, it was used interchangeably with the term nation or society; secondly, it was used to refer to inherited physical and mental attributes; thirdly, it was used in the context
} 
Very interesting is a narrative about the stillborn affair of a Croatian traveler named Hrvoje Grgurić (1893-1981), which he described in the book Na Dalekom Istoku (In the Far East). We include a Croatian writer in a text about Serbian and Polish literature because he served in the first Serbian Voluntary Division in Russia during the First World War, and his experience has a lot in common with the fate of Serbian soldiers who escaped to China from revolutionary Russia. ${ }^{24}$ Among more than sixty travel writers included in our research, he is the only one who explicitly describes a romantic but platonic relation with a Chinese girl. The girl named Tsi-Ču is described as "a small Asian", and is compared to a "miniature made of expensive Chinese porcelain". ${ }^{25}$ We should note that this characteristic is very stereotypical, taking away the girl's individuality and making her into some kind of a museum showpiece. Topicality of this characteristic suggests that a desire for the exotic Other is fundamental for Grgurić's initial fascination. The allure of another race means longing for transgression, mutual infatuation is described as the moment of negation of traditional barriers dividing two races and nations. ${ }^{26}$ When finally they meet in private, that moment of happiness is overshadowed by awareness of social norms that render the relationship impossible. Grgurić quotes a Tsi-Ču's monologue, in which the girl orders him, "an alien", to go away and then shereproaches him for making her soul restless by waking up feelings forbidden for her race. ${ }^{27}$ Analogically to Symonolewicz's remarks on interracial relationships, the final verdict is that racial differences are associated with insurmountable cultural barriers. The difference is that for the Polish author, racial differences manifest themselves in personalities, making a real understanding impossible, whereas for Grgurić love can defeat racial differences, but the reason for failure is social pressure. From this point of view, the Croatian author's account is similar to Wacław Sieroszewski's novel Zamorski diabet (A Foreign Devil), in which a romantic relationship between a Polish man and a Chinese girl is blooming despite racial difference, even though it is destroyed in the end by social pressure. On another level, in both texts we can see interracial relation as "a forbidden fruit", desire which cannot be fulfilled, because it will lead to catastrophe. Therefore, even if a description of mutual love suggests a possibility of crossing bounds of racial discourse in a personal relationship, however a composition of both stories only strengthens barriers created by race.

\section{'YELLOW PERIL'}

The idea of the 'yellow peril', mentioned in the first part of the article, constitutes one of the most important elements in racial discourse, so we shall

\footnotetext{
of historical rivalry among races (Magdalena Gawin, Rasa i nowoczesność. Historia polskiego ruchu eugenicznego (1880-1952), Warszawa: NERITON, Instytut Historii PAN 2003, pp. 138-139).

${ }^{24}$ About Grgurić's biography see Filip Hameršak, Nepoznati Hrvoje Grgurić, "Kolo: časopis Matice hrvatske" 2000 , t. 10, no 4, pp. 25-40.

${ }^{25}$ Hrvoje Grgurić, Na Dalekom Istoku. Uspomene našega dobrovoljca iz Sibirije, Mandžurije, Mongolije i Kine, Zagreb: Zaklad Tiskare Narodnih Novina 1931, p. 74.

${ }^{26}$ Ibidem, p. 81.

${ }^{27}$ Ibidem, p. 83.
} 
analyze a few examples of it. A very interesting semantic modification is found in Ariton Mihailović's book Kroz plamen ruske revolucije (Through the Fire of the Russian Revolution). As with the aforementioned Grgurić, Mihailović, a Serb, belonged to a group of Southern Slavic soldiers who fought for Russia during the First World War but escaped to East Asia after the Bolshevik Revolution. Having previously described Subotić's strategy as a 'persiflage' of racial discourse, in the case of Mihailović we can talk about 'contrafactum'. The idea of the 'yellow peril' becomes a carrier of Slavic messianism in the description of a Russian army parade: "Slavic peril, mentioned somewhere in the West, really exists more strongly than the 'yellow peril'. But it is an offensive word "peril". We are not perilous, but liberation and the best pioneers of freedom [...]". ${ }^{28}$

An intellectual rejection of the myth of the 'yellow peril' is presented in Karol Lanckoroński's book Na około Ziemi. 1888-1889. Wrażenia i poglady (Around the World. 1888-1889. Impressions and Opinions). Some travelers, e.g. Milan Jovanović and Przecław Smolik, responded to widespread stereotypes with an idealization of the Chinese, but this is not the case with Lanckoroński, who neither succumbed to the myth of the 'yellow peril' nor idealized East Asians; rather, in a rational manner he criticized some common opinions. Here is how he explained the causes of anti-Chinese fears: "The dirtiest envy for bread, which is a basis of anti-Chinese movement, is concealed under all possible national, religious and moral appearances". ${ }^{29}$ Lanckoroński is critical of symptoms of chauvinism and superstitions in social life, regardless of whether it is happening in China or America. In the next part of his refutation, Lanckoronski placed the idea of the 'yellow peril' within the framework of $19^{\text {th }}$ century social thought: "Racial hatred is a catchphrase of a dying century, which is trying to move a fight for survival from Darwin's theory into a wild practice among human tribes. Racial hatred replaced religious hatred of old times [...] and hatred of competing government systems, unbridled in the French Revolution". ${ }^{30}$ The 'yellow peril' is perceived as one manifestation of the racial discourse that is based on vulgar and social interpretation of Darwin's theory. In an interesting way, the writer compares racial hatred to other competing ideologies of the $19^{\text {th }}$ century, and in this way destabilizing racists' claims to scientific value by making it one more expression of social tensions and violent instincts. He also recognizes links between the 'yellow peril' and antisemitism, and in a critical way describes Aryan myth followers' lack of serious knowledge: "Persecutions of the Chinese can bring into America and Australia even worse consequences than a blind antisemitism in Europe, in Hong Kong and in other points in Asia's, 'Aryans' (what abuses are being done by conceited ignoramuses with this term of tribal descent about a substantial definition of which the most learned contemporaries have yet to be

\footnotetext{
${ }^{28}$ Ariton Mihailović, Kroz plamen ruske revolucije, Beograd 1928, p. 121. "Slovenska opasnost izgovorena negda na zapadu, odista postoji jače nego li žuta opasnost. Samo to je vređajuća reč 'opasnost'. Mi nismo opasnost, već Oslobođenje i najbolji pioniri slobode [...]".

${ }^{29}$ Karol Lanckoroński, Na około Ziemi. 1888-1889. Wrażenia i poglądy, Lwów: Gebethner i Spółka 1893, pp. 282-283. "Najbrudniejszą zawiść o chleb, będącą podstawą antychińskiego ruchu, osłania się płaszczykiem wszelkich możliwych narodowych, religijnych i moralnych pozorów”.

${ }^{30}$ Ibidem, p. 283. „Nienawiść rasowa jest hasłem umierającego stulecia, które walkę o byt z teorii Darwina przenieść usiłuje w dziką praktykę wśród szczepów ludzkich Nienawiść rasowa zastąpiła nienawiść religijną dawniejszych czasów [...] i rozkiełzaną we francuskiej rewolucyi nienawiść zwalczających się różnych ustrojów państwowych".
} 
agreed upon!) start to fear a revenge [...]". ${ }^{31}$ In a similar fashion, he condemns contradictions within racist critics of Chinese immigration, who on the one hand blame the Chinese for their isolation and not mixing with the rest of population, and on the other hand state that the yellow race will render the white race degenerated. To sum up, in Lanckoroński's writing we can see an intellectual critic of discrimination linked with racial discourse. Probably his criticism towards ideologies inspiring social upheavals may also have roots also in his aristocratic background.

Yet another perspective on the topic of race and the 'yellow peril' is given in travelogues written by Catholic priests. Bethencourt claims that the Catholic Church developed a universal view and "considered itself responsible for all the peoples of the world before God" as well as stressing the common behavior and reasoning among humans that constitute the essential basis for humanitas. ${ }^{32}$ Of course, doctrine is no guarantee that actions of representatives of the Catholic Church were free from racism. Furthermore, a firm conviction about the universal value of Christian revelation might lead to discrimination of other cultures and religions. Nevertheless, Polish travelers to China on behalf of the Catholic church had a comparatively incorporative attitude towards issues of race, even if their writings were full of ignorance and intolerance towards other religions and cultures. We can single out Ignacy Posadzy, Tadeusz Radkowski, Andrzej Krzesiński, and Władysław Michał Zaleski. None of them proposed any discrimination on racial ground, even if Andrzej Krzesiński, for example, argued with Gandhi that the only hope for India is the only true religion, the Catholic faith. ${ }^{33}$ Władysław Michał Zaleski had the highest office among them and is nowadays the best known, so we will focus on him. ${ }^{34}$ Zaleski was the Apostolic Delegate to the East Indies in the years 1890-1916, and during this time he traveled a great deal, including trips to Southeast Asia and China. He wrote many books, including a travelogue Podróż po Indo-Chinach r. 1897 i 1898 (Travel in Indochina in 1897 and 1898), in which he devoted attention to the issue of Chinese emigration. $\mathrm{He}$ rejects the idea of the 'yellow peril' in the name of missionary universalism: "A Catholic missionary looks at this issue from another angle, he is less concerned with the political and economic aspects, because for apostolic work all racial differences disappear: non enim est distinctio Judaei et Graeci". ${ }^{35}$ The universalism

\footnotetext{
${ }^{31}$ Ibidem, pp. 283-284. "Jeszcze gorsze skutki, niż ślepy antysemityzm w Europie, może w Ameryce i Australii pociągnąc za sobą prześladowanie Chińczyków, a osiedli w Hongkong i na innych punktach Azyi «Aryjczycy» (jakieżto nadużycia wyprawia dziś zarozumiałe nieuctwo z temi określeniami pochodzenia plemiennego, co do którego istotnej definicyi najuczeńsi z naszych współczesnych jeszcze się nie zgodzili!) poczynają już obawiać się odwetu [...]".

${ }^{32}$ Francisco Bethencourt, Racisms. From the Crusades to the Twentieth Century..., p. 39.

${ }^{33}$ Andrzej Krzesiński, $W$ krajach misyjnych Dalekiego Wschodu. Szkic, Poznań: Księgarnia św. Wojciecha 1939, p. 76.

${ }^{34}$ About Zaleski's life and writings see Witold Malej, Ks. W.M. Zaleski: delegat apostolski Indii Wschodniej, arcybiskup Teb, Patriarcha Antiochii, Rzym: Meridion 1965; George J. Lerski, Polish Prince of the Church in South Asia, "The Polish Review" 1984, vol. 29, no. 4, pp. 57-69; Tomasz Ewertowski, The Image of the Chinese in the Southeast Asian Contact Zone. National Comparisons in the Travelogues of Milan Jovanovic and Władysław Michat Zaleski, "Imagologiya i komparativistika" 2016, vol. 6 (2), pp. 40-57.

${ }^{35}$ Władysław Michał Zaleski, Podróż po Indo-Chinach r. 1897 i 1898, Kraków: nakł. aut. 1898, p. 63. "Missyonarz z innej strony spogląda na tę kwestyę; mniej go zajmuje strona polityczna lub
} 
of the Catholic Church leads to the conviction that Chinese migration, even if it may cause some political and economic problems, nonetheless it creates an opportunity for missionary activity. From this perspective, racial characteristics are far less important than confession, and according to Zaleski, converting to Catholicism can transform the Chinese: "One who has not touched, let me say, this issue with a hand cannot imagine how the Catholic faith changes a Chinese, how it ennobles him and how it develops his character traits positively, after having been so far overwhelmed by a pagan yoke". ${ }^{36}$ However, avoiding discrimination based on racial discourse does not mean that Zaleski was a writer free of prejudices. For example, in a quoted fragment, traditional Chinese culture is considered "a pagan yoke", and in general his writings are full of Eurocentric biases.

\section{BIBLIOGRAPHY}

Bethencourt Francisco, Racisms. From the Crusades to the Twentieth Century, Princeton-Oxford: Princeton University Press 2013.

Crowley David, Seeing Japan, Imagining Poland: Polish Art and the Russo-Japanese War, "The Russian Review”, 2008, vol. 67, no. January, pp. 50-69.

Cyrzyk Leszek, Literatura podróżnicza o Chinach w Polsce XIX w., "Przegląd Orientalistyczny" 1966, vol. 3 (59), pp. 205-216.

Dawson Raymond, The Chinese Chameleon. An Analysis of European Conceptions of Chinese Civilisation, New York: Oxford University Press 1967.

Dučić Jovan, Grof Sava Vladislavić: jedan Srbin diplomat na dvoru Petra Velikog i Katarine I, Valjevo: Glas crkve 2004, Izabrana dela u pet knjiga.

Ewertowski Tomasz, The Image of the Chinese in the Southeast Asian Contact Zone. National Comparisons in the Travelogues of Milan Jovanović and Władystaw Michat Zaleski, "Imagologiya i komparativistika" 2016, vol. 6 (2), pp. 40-57.

Ewertowski Tomasz, Slika Kine u "Tajnoj informaciji o snazi i stanju kineskog carstva" Save Vladislavića, "Dositejev vrt" 2014, vol. 2, pp. 71-93.

Fredrickson George M., Racism. A Short History, Princeton-Oxford: Princeton University Press 2002.

Gawin Magdalena, Rasa i nowoczesność. Historia polskiego ruchu eugenicznego (1880-1952), Warszawa: NERITON, Instytut Historii PAN 2003.

Grgurić Hrvoje, Na Dalekom Istoku. Uspomene našega dobrovoljca iz Sibirije, Mandžurije, Mongolije i Kine, Zagreb: Zaklad Tiskare Narodnih Novina 1931.

Gvozden Vladimir, Srpska putopisna kultura 1914-1940. Studija o hronotopičnosti susreta, Beograd: Službeni glasnik 2011, Biblioteka Književne nauke, umetnost, kultura.

Hameršak Filip, Nepoznati Hrvoje Grgurić, "Kolo: časopis Matice hrvatske" 2000, vol. 10, no. 4, pp. $25-40$.

Hannaford Ivan, Race: The History of an Idea in the West, Baltimore, London, Washington: Hopkins University Pres, Woodrow Wilson Center Press 1996.

Kajdański Edward, Dlugi cień wielkiego muru: jak Polacy odkrywali Chiny, Warszawa: Oficyna Naukowa 2005.

ekonomiczna, bo wobec apostolstwa nikną wszelkie różnice rasowe: non enim est distinctio Judaei et Graeci".

${ }^{36}$ Ibidem, p. 64. "Kto się tego nie dotknął, że tak powiem ręką, wyobrazić sobie nawet nie potrafi, jak wiara katolicka przekształca Chińczyka, ile go uszlachetnia i rozwija dodatnie strony jego charakteru, dotychczas przygniecionego pod jarzmem pogaństwa". 
Kałuski Marian, Polacy w Chinach, Warszawa: Instytut Wydawniczy PAX 2001.

Kapija od žada. Putopisi Srba o Kini: 1725-1935, ed. R. Pušić, Beograd: Biblioteka grada; Želnid 1998.

Keevak Michael, Becoming Yellow. A Short History of Racial Thinking, Princeton-Oxford: Princeton University Press 2011.

Konstanty Symonolewicz - orientalista, dyplomata, opiekun Polonii Mandżurskiej, ed. A. Winiarz, Szczecin: Książnica Pomorska im. Stanisława Staszica w Szczecinie 2012.

Krzesiński Andrzej, $W$ krajach misyjnych Dalekiego Wschodu. Szkic, Poznań: Księgarnia św. Wojciecha 1939.

Lanckoroński Karol, Na około Ziemi. 1888-1889. Wrażenia i poglądy, Lwów: Gebethner i Spółka 1893

Lerski George J., Polish Prince of the Church in South Asia, "The Polish Review" 1984, vol. 29, no. 4, pp. 57-69.

Mackerras Colin, Western Images of China, Oxford, New York: Oxford University Press 1989.

Malej Witold, Ks. W.M. Zaleski: delegat apostolski Indii Wschodniej, arcybiskup Teb, Patriarcha Antiochii, Rzym: Meridion 1965, Biblioteka Archiwum Archidiecezji Warszawskiej.

Mihailović Ariton, Kroz plamen ruske revolucije, Beograd 1928.

Mungello David E., The Great Encounter of China and the West, 1500-1800, Plymouth: Rowman \& Littlefield Publishing Group, Inc. 2009.

Podnebesko carstvo. Srbi o Kini 1725-1940 (putopisi i članci), ed. R. Pušić, Beograd: Čigoja štampa 2006.

Samii Darijuš, Ozren Subotić - novosadski istraživač Dalekog istoka, "Sveske za istoriju Novog Sada" 2016, no. 17, pp. 41-45.

Subotić Ozren, Iz žutog carstva, Novi Sad: Natošević 1921.

Symonolewicz Konstanty, Moi Chińczycy. 18 lat w Chinach, Warszawa: Biblioteka Polska 1938.

Thompson Carl, Travel writing, London-New York: Routledge 2011.

Velimirović Milutin, Kroz Kinu: putopis, Beograd: S. B. Cvijanović 1930.

Vladislavić Sava, Tajna informacija o snazi i stanju kineske države. Секретная информачія о силё и состояніи китайскаго государства, ed. V. Davidović, Beograd: Radio-televizija Srbije 2011.

Young Robert J.C., Colonial desire: hybridity in theory, culture, and race, London-New York: Routledge 1995.

Zaleski Władysław Michał, Podróż po Indo-Chinach r. 1897 i 1898, Kraków: nakł. aut. 1898.

Zapałowicz Hugo, Jedna z podróży na około Ziemi. Tom I, Lwów: Księgarnia Gubrynowicza i Schmidta 1899.

Лукин Александр Владимирович, Медведь наблюдает за драконом. Образ Китая в России в XVII-XXI веках, Москва: Восток-Запад: АСТ 2007.

Мясников Владимир Степанович, Посольство С. Л. Владиславича-Рагузинского в Пекин, in: Русско-китайские отношения в ХVIII веку. Том II. 1725-1727, ed. В.С. Мясников, Москва: Наука 1990.

\section{'YELLOW RACE' IN POLISH AND SERBIAN TRAVEL WRITING FROM THE SECOND HALF OF THE $19^{\mathrm{TH}}$ CENTURY AND THE FIRST HALF OF THE $20^{\mathrm{TH}}$ CENTURY}

\section{Summary}

Główny cel artykułu to analiza sposobu funkcjonowania dyskursu o żółtej rasie w polskim i serbskim podróżopisarstwie w drugiej połowie XIX i pierwszej połowie XX wieku 
oraz analiza semantyki terminu żółta rasa. Porównawcze ujęcie dwóch kultur słowiańskich, które nie uczestniczyły bezpośrednio w kolonialnej penetracji Chin, pozwala wprowadzić interesujący wymiar komparatystyczny. Trzy główne problemy rozważane w artykule to kwestia konfliktu ras, związków międzyrasowych oraz tzw. żółte niebezpieczeństwo.

Adj. Izabela Ślusarek 